\title{
Detection by PCR and analysis of the distribution of a fibronectin-binding protein gene $(f b n)$ among staphylococcal isolates
}

\author{
T. MINHAS, H. A. LUDLAM, M. WILKS and S. TABAQCHALI* \\ Department of Medical Microbiology, St Bartholomew's Hospital Medical College, West Smithfield, \\ London EC1A TBE
}

\begin{abstract}
Summary. The fibronectin-binding proteins of Staphylococcus aureus are considered to be important virulence factors for colonisation and infection. The polymerase chain reaction (PCR) was used to detect part of a gene equivalent to the $f b n A$ gene of $S$. aureus in 120 isolates of staphylococci ( $S$. aureus, S. epidermidis, S. haemolyticus, S. simulans, S. hominis, $S$. warneri, $S$. cohnii and $S$. lugdunensis). Primers specific for the binding domain region of the $f b n A$ gene of $S$. aureus produced PCR products of the predicted sizes (93 and $207 \mathrm{bp}$ ). The identity of the PCR products was confirmed by digestion with $D d e I$ and nucleic acid hybridisation. The fibronectin-binding activity of the staphylococci was determined with a particle agglutination assay (PAA). The $f b n$ gene was found to be present by PCR in 107 of the 120 staphylococci tested, irrespective of their site of isolation, and expression of the gene was detected by PAA in 101 of the 120 strains.
\end{abstract}

\section{Introduction}

Coagulase-negative staphylococci are an important and increasing cause of hospital-acquired infection. They are responsible for up to $26 \%$ of nosocomial bacteraemias, and are also the most common cause for the failure of prosthetic and implanted devices such as artificial heart valves, intravascular catheters, cerebrospinal fluid shunts and intraperitoneal catheters employed for continuous ambulatory peritoneal dialysis (CAPD)..$^{1 \cdot 3}$

Fibronectin plays a major role in adhesion between eukaryotic cells and has been shown to mediate adhesion between Staphylococcus aureus cells and host tissues. Fibronectin is a glycoprotein that is present in the body in two forms - a soluble dimeric form in fluids such as blood and plasma and a multimeric insoluble form deposited in extracellular matrix, connective tissue and implanted devices. ${ }^{4}$ Studies have shown that $S$. aureus synthesises fibronectin-binding proteins, ${ }^{5}$ and two highly homologous fibronectinbinding genes have been cloned and sequenced- $f b n A$ and $f b n B .^{6,7}$

Świtalski et $a l .^{8}$ demonstrated fibronectin binding

Received 26 Aug. 1993; revised version received 11 July 1994 accepted 15 Aug. 1994.

* Correspondence should be sent to Professor S. Tabaqchali. among coagulase-positive and -negative staphylococci, but with considerable variation in binding activity both between and within species, leading to the suggestion that various growth parameters may explain the variation in binding. More recent studies have produced conflicting results with regard to the role of host serum proteins, including fibronectin, in mediating staphylococcal adherence. ${ }^{9,10}$ Furthermore, Valentin-Weigand et al. ${ }^{11}$ demonstrated differences in adherence of coagulase-positive and -negative staphylococci in vitro depending on whether the fibronectin was in a soluble or immobilised form or incorporated into fibrin thrombi.

Since phenotypic expression of fibronectin-binding genes is variable, the aim of this study was to use the polymerase chain reaction (PCR) to investigate the distribution of a gene coding for a fibronectin-binding protein amongst staphylococci isolated either from sites of infection or as skin commensals. The primers were based upon nucleotide sequences common to both the $f b n A$ and $f b n B$ genes.

\section{Materials and methods}

\section{Bacterial isolates}

Thirty-eight staphylococcal isolates from the skin of healthy subjects, 30 isolates from patients with in- 
Table. Distribution of fibronectin-binding genes and activity amongst staphylococcal isolates

\begin{tabular}{|c|c|c|c|c|c|c|}
\hline \multirow{2}{*}{$\begin{array}{l}\text { Species } \\
\text { (total number } \\
\text { of isolates) }\end{array}$} & \multicolumn{2}{|c|}{ Skin isolates } & \multicolumn{2}{|c|}{$\begin{array}{l}\text { CAPD peritonitis } \\
\text { isolates }\end{array}$} & \multicolumn{2}{|c|}{$\begin{array}{l}\text { Endocarditis } \\
\text { isolates }\end{array}$} \\
\hline & $\mathrm{PCR}+\mathrm{ve}$ & $\mathrm{PAA}+\mathrm{ve}$ & $\mathrm{PCR}+\mathrm{ve}$ & PAA + ve & $\mathrm{PCR}+\mathrm{ve}$ & $\mathrm{PAA}+\mathrm{ve}$ \\
\hline S. aureus (30) & $11 / 11$ & $10 / 11$ & $9 / 9$ & $8 / 9$ & $9 / 10$ & $8 / 10$ \\
\hline S. epidermidis (33) & $7 / 7$ & $7 / 7$ & $7 / 9$ & $7 / 9$ & $15 / 17$ & $12 / 17$ \\
\hline S. haemolyticus (16) & $5 / 5$ & $5 / 5$ & $9 / 10$ & $9 / 10$ & $1 / 1$ & $1 / 1$ \\
\hline S. simulans $(7)$ & $5 / 6$ & $6 / 6$ & - & - & $1 / 1$ & $1 / 1$ \\
\hline S. hominis (6) & $5 / 5$ & $5 / 5$ & $1 / 1$ & $1 / 1$ & - & - \\
\hline S. warneri (5) & $2 / 4$ & $2 / 4$ & $1 / 1$ & $1 / 1$ & - & - \\
\hline S. lugdunensis (3) & - & -1 & $2 / 2$ & $1 / 2$ & $1 / 1$ & $1 / 1$ \\
\hline S. intermedius (2) & - & - & $1 / 2$ & $1 / 2$ & - & - \\
\hline S. saprophyticus (1) & - & - & $1 / 1$ & $1 / 1$ & - & - \\
\hline$S$. capitis $(2)$ & — & - & $1 / 2$ & $1 / 2$ & - & - \\
\hline
\end{tabular}

fective endocarditis and 37 isolates from CAPDassociated peritonitis were tested. The species distribution is shown in the table. In addition, the following reference strains were included: $S$. aureus NCTC $6571 ; S$. aureus NCTC $08532 ; S$. auricularis NCTC $12101 ;$ S. capitis NCTC 11045; S. cohnii NCTC 11041; S. epidermidis NCTC 11047; S. haemolyticus NCTC 11042; S. hominis NCTC 1320; S. intermedius NCTC 11048; S. saprophyticus NCTC 07292; S. simulans NCTC 11046; S. warneri NCTC 11044; $S$. xylosus NCTC 11043; M. luteus NCTC 02665; and $M$. roseus NCTC 07521. All isolates were collected and speciated as described by Ludlam et al. ${ }^{12}$

\section{DNA preparation}

Bacteria were cultured aerobically on blood agar (defibrinated horse blood 5\% v/v in Oxoid Nutrient Broth no. 2 plus agar $1.5 \% \mathrm{w} / \mathrm{v}$ ), harvested after incubation for $18 \mathrm{~h}$ at $37^{\circ} \mathrm{C}$, and washed in phosphatebuffered saline $(\mathrm{pH} 7 \cdot 3)$. The cells were then incubated in lysostaphin (Sigma) $0.2 \mathrm{mg} / \mathrm{ml}$ at $37^{\circ} \mathrm{C}$ for $3 \mathrm{~h}$; the supernate was discarded after centrifugation at $3000 \mathrm{~g}$ for $2 \mathrm{~min}$. The deposit was resuspended in $0.5 \mathrm{ml}$ of $5 \mathrm{~m}$ guanidium thiocyanate (Sigma) and, after vortex mixing for $30 \mathrm{~s}, 0.25 \mathrm{ml}$ of cold $7.5 \mathrm{M}$ ammonium acetate was added. The solution was mixed by gentle inversion and left on ice for $10 \mathrm{~min}$. Chloroform:2pentanol $(24: 1, \mathrm{v}: \mathrm{v})$ was added, mixed by inversion and vortex mixed for $20 \mathrm{~s}$ to form an emulsion. The emulsion was centrifuged at $13000 \mathrm{~g}$ for $5 \mathrm{~min}, 0.54$ volumes of isopropanol were added to the upper layer, mixed and centrifuged as above to precipitate the DNA. The DNA was then washed three times with $1 \mathrm{ml}$ of ethanol $70 \% \mathrm{v} / \mathrm{v}$, dried under vacuum and dissolved in $100 \mu \mathrm{l}$ of sterile water. The concentration of DNA was estimated by separation on agarose gels with 1- $\mu \mathrm{g}$ amounts of lambda-Hind III digests (Pharmacia) followed by visual comparison of the intensity of the bands.

\section{Polymerase chain reactions}

Primers were based on sequenced areas of the $f b n A$ gene of $S$. aureus (the $f b n B$ nucleotide sequence was almost identical in these regions) which were most likely to be highly conserved amongst staphylococci. ${ }^{6}$ The primers used were as follows: primer F1 (5'GGTAATCAGTCATTCGAG-3'); primer R1 (5'TGGCACACTGTCGAAGTC-3'); and primer Mr1 (5'-TGCGTAATAATGCTAAAC-3'). Primers were synthesised with a Model 391 EP Oligonucleotide Synthesiser (Applied Biosystems, Warrington, Cheshire).

The PCR mixture consisted of $70 \mu \mathrm{l}$ of sterile distilled water, $16 \mu \mathrm{l}$ of dNTPs $(0.2 \mathrm{~mm}$ each; Pharmacia), $10 \mu \mathrm{l}$ of reaction buffer (Taq polymerase buffer $\times 10$; Amersham), $1 \mu \mathrm{l}$ of each primer $(20 \mathrm{nmol}), 1$ unit of Taq polymerase (Amersham) and $3 \mu \mathrm{l}$ of template DNA (300 ng). The mixture was overlaid with $100 \mu \mathrm{l}$ of sterile mineral oil. After an initial denaturation step $\left(96^{\circ} \mathrm{C}\right.$ for $\left.2 \mathrm{~min}\right), 40$ amplification cycles of $94^{\circ} \mathrm{C}$ for $1 \mathrm{~min}, 55^{\circ} \mathrm{C}$ for $30 \mathrm{~s}$ and $72^{\circ} \mathrm{C}$ for $1 \mathrm{~min}$ were performed in a Hybaid Thermal Reactor, with a final 10 -min extension step at $72^{\circ} \mathrm{C}$. PCR products were separated on an agarose $1.5 \%$ $\mathrm{w} / \mathrm{v}$ gel containing ethidium bromide $(1 \mu \mathrm{g} / \mathrm{ml})$ and visualised on an ultraviolet transilluminator.

\section{Southern blotting and hybridisation procedure}

The PCR-amplified products from various isolates were transferred to Hybond-N nylon membrane (Amersham). The 93-bp amplified product from $S$. epidermidis strain 1220.1 was used as the probe in hybridisation experiments. Hybridisations were carried out under conditions of high stringency (formamide $50 \% \mathrm{v} / \mathrm{v}$, a hybridisation temperature of $42^{\circ} \mathrm{C}$, and three washes performed at $42^{\circ} \mathrm{C}, 65^{\circ} \mathrm{C}$ and $42^{\circ} \mathrm{C}$ ). Wash solution 1 contained $1 \mathrm{M}$ Tris $(\mathrm{pH} \mathrm{8.0)}$, $3 \mathrm{M} \mathrm{NaCl}$ and $0.5 \mathrm{M}$ EDTA; solution 2 was the same as solution 1, but also contained SDS $10 \% \mathrm{w} / \mathrm{v}$; the third wash solution was a 10 -fold dilution of the first wash solution. The probe was radiolabelled with $\left[\alpha^{32} \mathrm{P}\right]-$ 


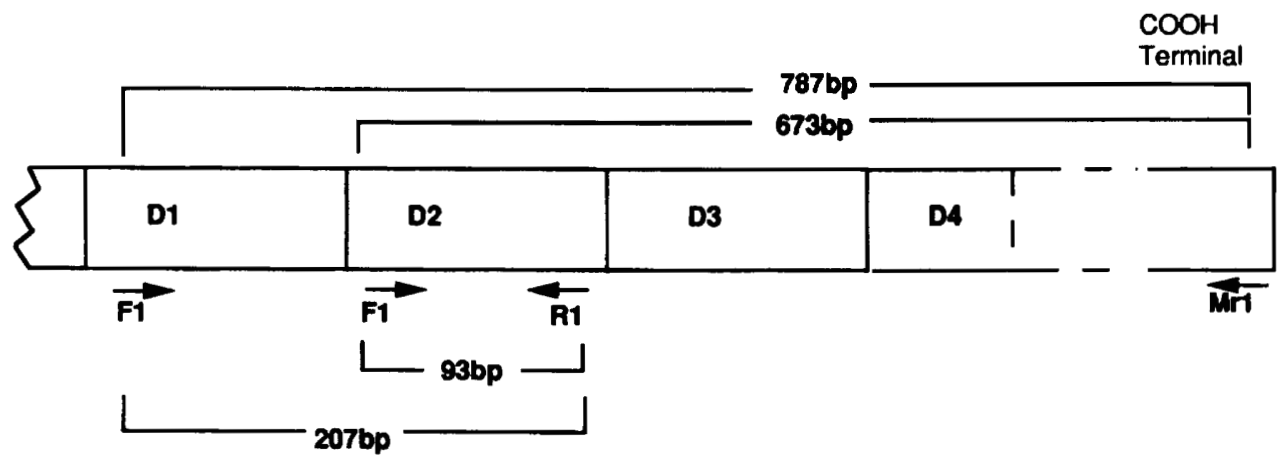

Fig. 1. Schematic illustration of part of the $f b n A$ gene of $S$. aureus showing the sites to which primers F1, R1 and Mrl annealed to produce amplified products. Repeating units are designated D1-D4.

dCTP (Amersham) by the random sequence hexamer method of Feinberg and Vogelstein. ${ }^{13}$ All blots were dried and exposed to Fuji-RX X-ray film at $-70^{\circ} \mathrm{C}$ for 1-3 days.

\section{Preparation of fibronectin-coated latex reagents}

One $\mathrm{ml}$ of latex particle suspension (bead diameter $0.8 \mu \mathrm{m}$; Sigma) was mixed with $3 \mathrm{ml}$ of $0.17 \mathrm{M}$ glycine- $\mathrm{NaOH}$ buffer ( $\mathrm{pH} 8 \cdot 2$ ), centrifuged at $4500 \mathrm{~g}$ for $5 \mathrm{~min}$, and the pellet was resuspended in $3 \mathrm{ml}$ of the same buffer. Highly purified fibronectin $(100 \mu \mathrm{g})$ from human plasma (Sigma) was added and mixed at $30^{\circ} \mathrm{C}$ for $12 \mathrm{~h}$ on a shaker. The mixture was centrifuged at $9200 \mathrm{~g}$ for $5 \mathrm{~min}$ at room temperature and the supernate was discarded. The pellet was resuspended in $2 \mathrm{ml}$ of the glycine- $\mathrm{NaOH}$ buffer containing ovalbumin $(0.01 \% \mathrm{w} / \mathrm{v}$; Sigma) and methiolate $\left(0.01 \% \mathrm{w} / \mathrm{v}\right.$; Sigma), and kept at $4^{\circ} \mathrm{C}$ for $12 \mathrm{~h}^{14}$

\section{Particle agglutination assay $(P A A)$}

Isolates were grown on blood agar at $37^{\circ} \mathrm{C}$ for $24 \mathrm{~h}$. Cells were resuspended and washed in $0.02 \mathrm{M}$ potassium phosphate buffer $(\mathrm{pH} \mathrm{6.8)}$ and then resuspended in the same buffer to a density of MacFarland standard no. $5\left(c .10^{9}\right.$ cells $\left./ \mathrm{ml}\right)$, followed by immediate testing in the PAA. Reactivity was observed by mixing one $20-\mu \mathrm{l}$ drop of bacterial suspension on a glass slide with $20 \mu \mathrm{l}$ of fibronectincoated latex particles. Any agglutination occurring within 2 min was recorded as positive, and any agglutination after 2 min was recorded as a negative result. ${ }^{14}$ The micrococci reference strains were included as negative controls and did not agglutinate. Uncoated beads were not used as negative controls because of the high incidence of non-specific agglutination of uncoated latex beads. ${ }^{15}$

\section{Reproducibility}

All PCR, PAA and hybridisation studies were performed in duplicate.

\section{Results}

\section{Amplification of fbn gene fragments}

Primers F1 and R1, based on the sequence data of the $f b n A$ gene of $S$. aureus, were used in PCR reactions with template DNA from staphylococcal isolates. Fig. 1 illustrates the fibronectin-binding region of the gene to which the primers annealed to yield 93- and 207-bp products. The four repeating units (D1-D4) are adjacent to each other. Primer F1 annealed at two sites within the D1 and D2 units of the $f b n$ gene, whereas primer R1 annealed to a single site within the D2 unit. Fig. 2 shows an example of the products obtained (93 and $207 \mathrm{bp}$ ) from 107 of the 120 strains with primers F1 and R1. The table shows the proportion of the 105 clinical isolates that were PCR-positive or -negative. The identity of the two PCR products was investigated by digesting the products with $D d e I$ since a unique DdeI site exists within the D2 repeating unit of the $f b n A$ gene of $S$. aureus. Fig. 3 shows the effect of digesting the 93- and 207-bp products with DdeI. A single band of $c .40-50 \mathrm{bp}$ was observed when the 93bp product was digested, instead of the two expected fragments of $52 \mathrm{bp}$ and $41 \mathrm{bp}$, probably because of the limited resolution of the agarose gel. The larger PCR product (207 bp), which includes amplification of part of the adjacent D1 repeating unit in addition to the 93bp product, was restricted at the same site and yielded two visible bands of $52 \mathrm{bp}$ and $155 \mathrm{bp}$. As expected, the two strains of micrococci, $M$. luteus (NCTC strain 02665) and $M$. roseus (NCTC strain 07523), did not yield any amplification products. Not all isolates produced both a 93- and a 207-bp product.

The 93-bp amplified fragment from $S$. epidermidis strain 1220.1 was confirmed to be part of the $f b n A / f b n B$ genes from nucleotide sequence data (data not shown). There was very close homology between the $S$. aureus $f b n A / B$ gene sequence data and the nucleotide sequence of the PCR products.

\section{Hybridisation of ${ }^{32} P-P C R$ products to amplified products and digested $D N A$}

Further confirmation of the identity of the PCR products was obtained by nucleic acid hybridisations. 


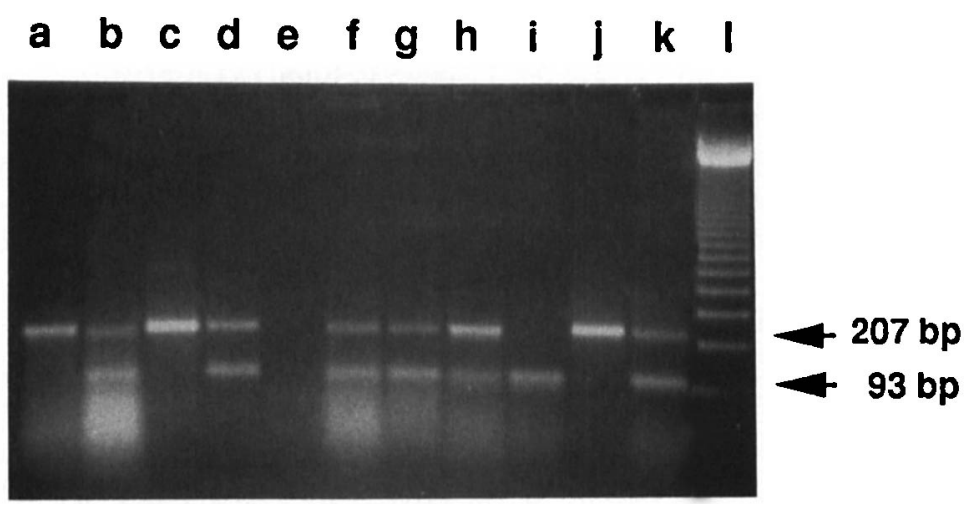

Fig. 2. Example of PCR amplification of 207- and 93-bp products (with primers F1 and R1) visualised on an ethidium bromide-stained agarose $1.5 \% \mathrm{w} / \mathrm{v}$ gel. Lanes: a, S. aureus strain Abk; b, S. aureus Oxford strain; $\mathbf{c}$, S. aureus strain Dhk; d, S. epidermidis strain DLe; e, Dhk negative control ; f, S. haemolyticus strain Pts; g, S. epidermidis strain Ev; h, S. hominis strain Fst; i, S. lugdunensis strain Gly; j, S. aureus strain Wwd; k, S. epidermidis strain NCTC 11047; 1, 100-bp ladder marker (Promega).

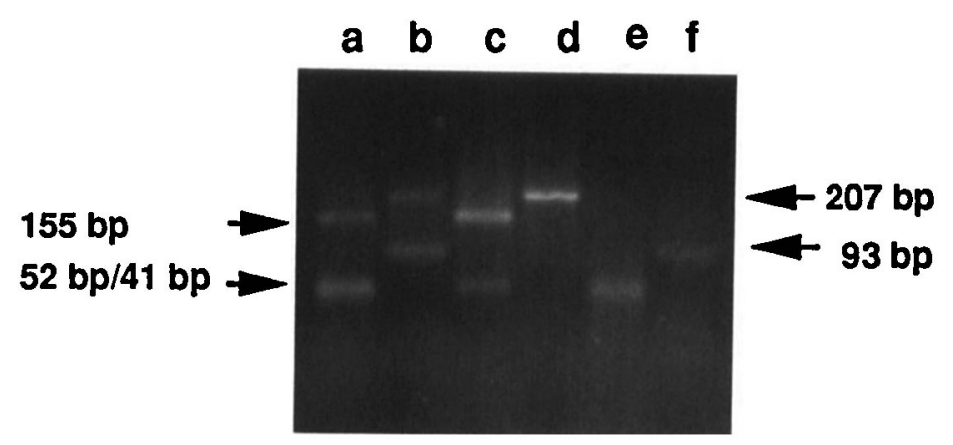

Fig. 3. Examples of the digestion of PCR products with DdeI. Lanes: a, DdeI-digested products of 155,52 and 41 bp from S. epidermidis strain 1220.1 ; b, undigested PCR products of 207 and 93 bp from strain 1220.1 ; c, DdeI-digested products of 155 and 52 bp from S. aureus strain Dhk; d, undigested PCR product of 207 bp from strain Dhk; e, DdeI-digested products of 52 and 41 bp from S. lugdunensis strain Gly; and f, undigested PCR product of 93 bp from strain Gly.

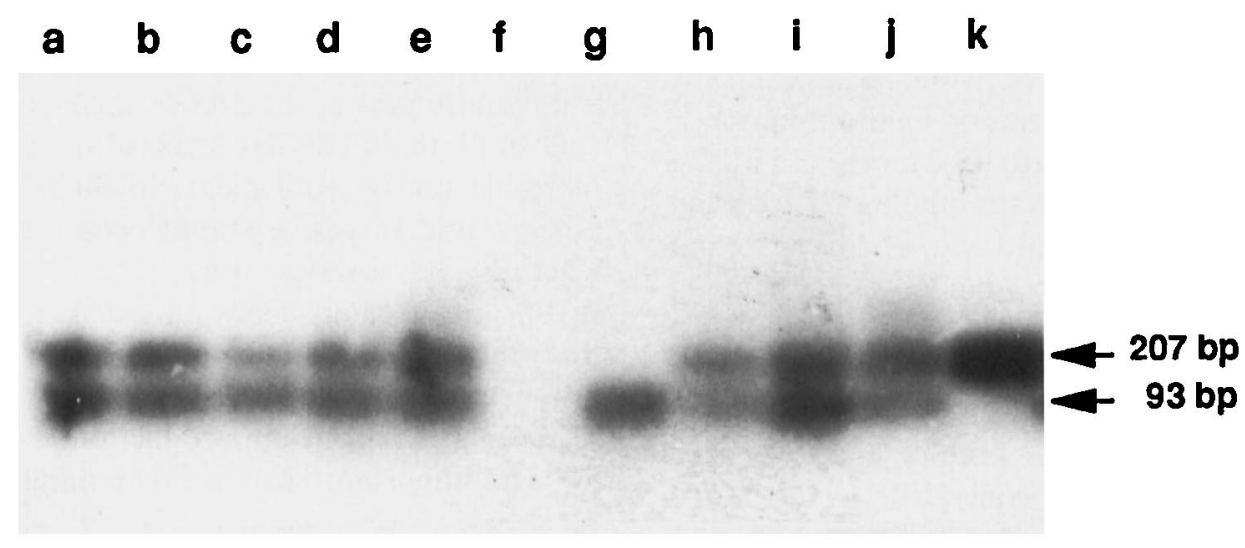

Fig. 4. Autoradiograph of a Southern blot of the 207- and 93-bp PCR products from various staphylococcal species hybridised with the ${ }^{32} \mathrm{P}$ labelled 93-bp amplified product from S. epidermidis strain 1220.1. Lanes: a, S. epidermidis strain 1220.1 (positive control); b, S. hominis strain Fst; c, S. haemolyticus strain Pst; d, S. warneri strain Mng; e, S. epidermidis strain Ev; f, M. roseus NCTC strain 07523 DNA (negative control); g, S. lugdunensis strain Gly; h, S. simulans strain Ly; j, S. aureus Oxford strain; $\mathbf{k}, S$. aureus strain Dhk.

Fig. 4 shows the results of a high-stringency hybridisation reaction between amplified fragments from clinical staphylococcal isolates or skin commensals and the radiolabelled 93-bp PCR product from $S$. epidermidis strain 1220.1. This result indicated that the 93- and 207-bp PCR products were part of a gene equivalent to the $S$. aureus $f b n A$ and $B$ genes. The 207bp product was also shown to include the 93-bp fragment, as indicated in fig. 1, because primer F1 anneals to two almost identical sites.
A 673-bp PCR product was amplified from $S$. epidermidis strain 1220.1 when primers $\mathrm{F} 1$ and $\mathrm{Mr} 1$ were used. The Mrl primer was based on the sequence for the membrane-spanning region at the carboxyl terminal of the $f b n$ gene. The 673-bp product was an extension of the 93- and 207-bp fragments (as confirmed by nested PCR; results not shown). 


\section{$P A A$}

It is evident from the table that most (101 of 120) of the staphylococcal isolates, irrespective of their coagulase reaction or site of origin, agglutinated fibronectin-coated latex beads. However, one isolate from skin ( $S$. simulans) repeatedly gave no PCR product, but a positive agglutination reaction. A comparison of the results obtained by PCR and PAA (table) indicated a good correlation between the two techniques. The PCR data showed a high level of distribution of the $f b n$ gene among many species of staphylococci isolated from different sites. The DNA of 95 clinical isolates produced either $93-$ or $207-b p$, or both, PCR products. Most of this "positive group" (92 of 95) had the 93-bp product, although many of them also had the 207-bp fragment (74 of 95). A few isolates ( 3 of 95 ) produced only the 207-bp product following PCR amplification.

\section{Discussion}

The increasing problem of nosocomial infection with coagulase-negative staphylococci has provided an urgent stimulus to investigate the poorly understood pathogenic mechanisms and virulence determinants of these opportunist pathogens. Increasing evidence of the importance of fibronectin-binding proteins in colonisation by $S$. aureus has stimulated an interest in the interaction of coagulase-negative staphylococci with fibronectin. To date there have been few studies of this interaction, all of which have been at the phenotypic level, with variable results attributed to different laboratory methodology. ${ }^{11,16}$ This study attempted, firstly, to shed more light on the accuracy of tests for fibronectin binding by focusing on the development of a rapid and sensitive method for detecting the fibronectin-binding gene among staphylococci, and secondly, to assess the pathogenic importance of fibronectin binding by comparing skin commensals and clinical isolates.

Primers based on the $f b n A$ gene of $S$. aureus were used to detect this or an equivalent gene among coagulase-negative staphylococci. The primers (F1 and $R 1$ ) based on a repeating unit region (D repeats) produced amplified products consistently from 107 of the 120 isolates tested. It is likely that this area of the gene is highly conserved, as most species of staphylococci tested produced either 93- or 207-bp (or both) products; this was confirmed for S. epidermidis strain 1220.1 by nucleotide sequence data (unpublished results). The most likely explanation for both products not being amplified in all of the 107 isolates is that of genetic polymorphism at the annealing sites. In the isolates where a product was amplified, it was assumed that the whole $f b n$ gene was present, and this was confirmed for 106 of the 107 isolates by demonstrating activity by PAA. The PAA ${ }^{14,15}$ was chosen as a rapid screening method primarily because of the technical disadvantages of using the ${ }^{125}$ I-fibronectin technique, ${ }^{5}$ and the PAA method proved to be reliable and reproducible under the in-vitro test conditions described.

The strong correlation between the PAA data and the PCR results confirmed that the whole $f b n$ gene was present in most isolates. Seven of the 120 isolates produced a PCR product, but did not agglutinate fibronectin-coated latex particles. Possibly the cells could bind fibronectin in its immobilised form. Valentin-Weigand et al. ${ }^{11}$ have demonstrated varied ability among staphylococci to bind to different forms of fibronectin (i.e., soluble, immobilised and incorporated).

One skin isolate of $S$. simulans produced no PCR product, but the cells agglutinated fibronectin-coated latex particles. This could possibly result from either autoagglutination by the cells (a false PAA-positive) or a false-negative by the PCR reaction. The latter may be possible if the D-repeating region of this isolate has low homology with the $S$. aureus $f b n A$ gene or if there is polymorphism at the primer annealing site(s).

Overall, this study has detected the presence of the $f b n$ gene (or its equivalent) in $90 \%$ of coagulasepositive and -negative staphylococci, irrespective of whether the isolates were regarded as clinically significant or commensals on the skin. The fact that this gene is present and being expressed in such a high proportion of coagulase-negative staphylococci suggests that fibronectin production per se is unlikely to be an important virulence determinant.

This work was supported by a grant from the Joint Research Board of St Bartholomew's Hospital. We thank Dr H. Kleanthous for his helpful comments during the preparation of this manuscript.

\section{References}

1. Eykyn SJ. Staphylococcal sepsis. The changing pattern of disease and therapy. Lancet 1988; 1: 100-104.

2. Ludlam HA, Noble WC, Marples RR, Bayston R, Phillips I. The epidemiology of peritonitis caused by coagulasenegative staphylococci in continuous ambulatory peritoneal dialysis. J Med Microbiol 1989; 30: 167-174.

3. Patrick CC. Coagulase-negative staphylococci: pathogens with increasing clinical significance. $J$ Pediatrics $1990 ; 116$ : 497-507.

4. Ruoslahti E, Engvall E, Hayman EG. Fibronectin: current

concepts of its structure and functions. Coll Relat Research 1981; 1 : $95-128$.

5. Kuusela P. Fibronectin binds to Staphylococcus aureus. Nature 1978; 276: 718-720.

6. Signas C, Raucci G, Jonsson K et al. Nucleotide sequence of the gene for a fibronectin-binding protein from Staphylococcus aureus: use of this peptide sequence in the synthesis of biologically active peptides. Proc Natl Acad Sci USA 1989; 86: 699-703.

7. Jonsson K, Signas C, Muller HP, Lindberg M. Two different genes encode fibronectin binding proteins in Staphylococcus aureus. The complete nucleotide sequence and 
characterization of the second gene. Eur J Biochem 1991; 202: 1041-1048.

8. Świtalski LM, Rydén C, Rubin $\mathrm{K}$, Ljungh A, Höök $\mathbf{M}$, Wadström T. Binding of fibronectin to staphylococcus strains. Infect Immun 1983; 42: 628-633.

9. Vaudaux P, Pittet D, Haeberli A et al. Host factors selectively increase staphylococcal adherence on inserted catheters: a role for fibronectin and fibrinogen or fibrin. $J$ Infect Dis $1989 ; 160$ : 865-875.

10. Muller E, Takeda S, Goldmann DA, Pier GB. Blood proteins do not promote adherence of coagulase-negative staphylococci to biomaterials. Infect Immun 1991; 59: 3323-3326.

11. Valentin-Weigand P, Timmis KN, Chhatwal GS. Role of fibronectin in staphylococcal colonisation of fibrin thrombi and plastic surfaces. J Med Microbiol 1993; 38: 90-95.

12. Ludlam HA, Noble WC, Marples RR, Phillips I. The evaluation of a typing scheme for coagulase-negative staphylococci suitable for epidemiological studies. J Med Microbiol 1989; 30: $161-165$.

13. Feinberg AP, Vogelstein B. A technique for radiolabeling DNA restriction endonuclease fragments to high specific activity. Ann Biochem 1983; 132: 6-13.

14. Naidu AS, Paulsson M, Wadström T. Particle agglutination assays for rapid detection of fibronectin, fibrinogen, and collagen receptors on Staphylococcus aureus. J Clin Microbiol 1988; 26: 1549-1554.

15. Dunne WM, Burd E. Autoagglutination and Latex particle agglutination assays. J Clin Microbiol 1992; 30: 3298 .

16. Paulsson M, Ljungh A, Wadström T. Rapid identification of fibronectin, vitronectin, laminin, and collagen cell surface binding proteins of coagulase-negative staphylococci by particle agglutination assays. J Clin Microbiol 1992; 30: 2006-2012. 